\section{Autonomia e seus limites na vida pública}

\section{Marchi, Neiva De}

Psicóloga, doutora em Bioética pelo Centro Universitário São Camilo/SP, preceptora da Residência Médica na Rede Metropolitana de Saúde, Sarandi/Paranál e-mail: neiva.marchi@hotmail.com

\section{Ravagnani, Milton}

Advogado, jornalista, docente do Curso de Direito do Centro Universitário Ingá, Maringá/Pr

\section{Marchi, Daniel Catto De}

Médico, residente em clínica geral da Santa Casa de Maringál $\operatorname{Pr}^{3}$, Brasil.

PALAVRAS-CHAVE: Dignidade, Autonomia, Corpo Social.

Com a evolução do pensamento moderno, cada dia mais se cristaliza o entendimento de que nenhum direito é absoluto, nem mesmo os personalíssimos. Quando observamos os direitos relativizados quanto à honra, à imagem, à informação, à liberdade e até à vida, não é possível imaginar uma autonomia que seja ilimitada. A questão é saber o que pode limitar a autonomia de alguém. A tradição Iluminista assevera que deva existir a separação entre os âmbitos público e privado, Estado e Igreja, no intuito de preservar e respeitar a diferença funcional do corpo social, imprescindível para o funcionamento adequado das sociedades complexas, dotadas de um pluralismo de interesses, valores e crenças. Nesse sentido, resta entendermos se a autodeterminação se insere na ideia de que todo ser humano deve decidir e deliberar sobre si mesmo, não relevando se sua conduta pareça justa ou boa, ou se não são passíveis de julgamento as razões que levam, levaram ou levarão uma pessoa a pensar ou agir de determinada forma. A dignidade do outro se apresenta como limitadora de nossa autonomia. Sendo assim, estamos incitados a enfrentar novos desafios na esfera da Bioética: a autonomia quando limitada pela dignidade do outro, sugere ser limitada pelo interesse coletivo ou, na sua acepção jurídica, pelo interesse público. A partir de uma pesquisa bibliográfica e uma análise orientada pela bioética hermenêutica, este estudo procurou refletir a ação individual sobre o coletivo, entendendo a limitação da autonomia, onde não mais cabe ao indivíduo impor sua vontade como direito e exigir do Estado sua garantia, como havia no mundo privatista da sociedade liberal. O interesse coletivo é elemento de mitigação da liberdade individual e alcança, inclusive, a autonomia do indivíduo, que é seu núcleo indevassável da dignidade.
[1] GARRAFA, V.; PORTO, D. Intervention bioethics: a proposal for peripheral countries in a context of power and injustice. Bioethics, v. 17, n. 5-6, p. 399-416, 2003.

[2] HORKHEIMER, M.; ADORNO, T. A indústria cultural: o iluminismo como mistificação de massas. In: LIMA, Luiz Costa. Teoria da cultura de massa. São Paulo: Paz e Terra, 2002.

[3] SCHNEEWIND, J. B. A invenção da autonomia. São Leopoldo: Editora Unisinos, 1999.

[4] SEGRE, Marco; SILVA, Franklin Leopoldo; SCHRAMM, Fermin Roland. O Contexto Histórico, Semântico e Filosófico do Princípio de Autonomia. Revista Bioética, v. 6, n. 1, 2009.

[5] SEN, Amartya. Desigualdade Reexaminada. Rio de Janeiro: Record, 2001.

\title{
REFERÊNCIAS
}

